\title{
Forming a Collaborative Community of Practice of EFL Teachers through Self-study Research
}

\author{
Chitose Asaoka $^{1, *}$, Daisuke Miura ${ }^{2}$, Taiki Okubo ${ }^{3}$ \\ ${ }^{1}$ Faculty of Foreign Languages, Dokkyo University, Soka, Japan \\ ${ }^{2}$ Toho Gakuen Music High School, Chofu, Tokyo, Japan \\ ${ }^{3}$ Takasaki High School, Takasaki, Gunma, Japan
}

Received March 22, 2020; Revised July 10, 2020; Accepted July 20, 2020

\section{Cite This Paper in the following Citation Styles}

(a): [1] Chitose Asaoka, Daisuke Miura, Taiki Okubo , "Forming a Collaborative Community of Practice of EFL Teachers through Self-study Research," Universal Journal of Educational Research, Vol. 8, No. 9, pp. 3799 - 3806, 2020. DOI: 10.13189/ujer.2020.080902.

(b): Chitose Asaoka, Daisuke Miura, Taiki Okubo (2020). Forming a Collaborative Community of Practice of EFL Teachers through Self-study Research. Universal Journal of Educational Research, 8(9), 3799 - 3806. DOI: 10.13189/ujer.2020.080902.

Copyright@2020 by authors, all rights reserved. Authors agree that this article remains permanently open access under the terms of the Creative Commons Attribution License 4.0 International License

\begin{abstract}
The current study is a self-reflective autoethnographic research study, which aims to explore how two in-service English as a foreign language (EFL) teachers in Japan built a collaborative and mutually supportive community of practice, and how they shared and re-constructed their expertise through interacting with each other. Prior to the study, both of the participating teachers from different teaching contexts shared a similar struggle: a lack of collegiality and a quest for creativity. An online journal forum was created where they recorded their thoughts, difficulties and challenges in their everyday teaching practice for one year. They also gave comments and feedback to each other online. As a result, participation in an online collaborative community of practice enabled them to reflect on and adjust their teaching practices. In particular, the role of collegiality in sharing teaching strategies impacted the teaching of English as a foreign language in diverse contexts, both public and private schools. It also had an impact on teaching different language skills (oral communication for one participant and reading and translation for the other) and the use of students' native language as assistance. By taking on the role of a diagonal mentor, they also found a way to make their professional voices heard.
\end{abstract}

Keywords Teacher Development, Self-study Research, Collaboration, Collegiality, Community of Practice, Reflective Practice, Mentor

\section{Introduction}

The lack of collegiality in the professional development of language teachers is one of many issues facing teachers in their everyday practice in many teaching contexts. This lack of collegiality often results in low job satisfaction and high stress for teachers [1]. Thus, creating a space and the means for their professional voices to be heard is essential in teacher professional development.

This self-reflective autoethnographic research study therefore created such a space for the participants' voices to construct collegiality in their professional development. Self-study, originating from previous works such as reflective practice theory [2-5] and action research [6], has become a widely used approach in the professional development research of teachers [7]. It is a methodology for studying professional practice [8], and is a mode of scholarly inquiry in which teachers examine their beliefs and actions within the context of their work as practitioners [9]. Personal narratives of practicing teachers through self-study and changes in their perspectives over time can illustrate their voices. They can share their experiences of introspection and personal growth as teachers, which can then promote insight and interpretation [10]. Self-study can also provide a glimpse into what researchers and teacher educators often take for granted. It is worth-noting, however, that self-study usually relies on interaction with "close colleagues who can listen actively and constructively” (Russell: 5)[11]. In 
other words, teachers in autobiographical self-study research may promote the improvement of learning situations "not only for the self but for the other" (Bullogh \& Pinnegar: 17). In fact, this notion is in line with Vygotskian sociocultural theory, which views learning as a social process that takes place within communities of practice [12][13]. When teachers participate in a community of practice, interaction and negotiation with other members is essential for the development of teacher expertise)[14]. Williams \& Ritter [15] also argue that shared and collaborative inquiries of practice will "increase social support, foster a culture of reflection and help avoid solipsism” (83).

Therefore, this study focused on building a collaborative community of practice of teachers, and explored how the participants shared and re-constructed their expertise through interaction with each other.

\section{Context of the Study and Methodology}

In the current study, two English as a foreign language (EFL) teachers in Japan are featured. At the onset of the project, Daisuke had been teaching English both at a high school and college for a total of three years, while Taiki had been teaching English in secondary school for five years. Their teaching contexts were quite different; Daisuke taught at a small private school which focused on music education with relatively few colleagues (only two full-time English teachers, including himself) whereas Taiki taught at a large public school which focused on preparing students to be admitted to prestigious universities, and he had to work in a team of three English instructors teaching the same grade. Both Daisuke and Taiki graduated from the same initial-teacher-education programme, where the first author worked as a teacher educator. They also shared common concerns in their teaching: a lack of collegiality and a quest for creativity. When the first author invited Daisuke and Taiki to join a professional development project supported by one Special Interest Group of JACET (Japan Association of College English Teachers), they met in person, and were able to discuss their struggles in different teaching contexts. The current study grew out of this discussion, and building collaborative and mutually supportive communities of practice became the focus of this particular study.

Keeping a journal is often used as a strategy to help teachers think about their own teaching and develop their teacher expertise [1]. Moreover, previous literature supports the benefits of online professional development. For example, Kabilan et al. [16] argue that teachers' online collaboration is beneficial and meaningful for their professional development. Lock [17] also advocates for an online community of teachers to facilitate teacher professional development. Thus, in this study, the first author created an online journal forum (from April 2018 until January 2019) where Daisuke and Taiki recorded what happened in their classrooms. They kept a note of their difficulties as well as solutions, and gave comments to each other. The first author also joined, occasionally asking about and commenting on their journal entries as well in order to promote a more constructive discussion. There were no particular rules in terms of the topics, frequency, and number of posts. We also met twice in person to share their teaching experiences and feelings about joining this online community of practice: the first focus group interview took place in April 2018, and the second one occurred in September 2018. The first author also interviewed them individually at the end of this project in February 2019. Finally, the first author asked Daisuke and Taiki to reflect on their journal entries and their teaching experiences over the year and to write a reflective essay, particularly on the following topics: challenges prior to the project, improvements over the year, breakthroughs in their professional learning, and the benefits of joining an online collaborative community of practice. In the following section, a combination of journal postings, interviews, and final reflective essays was used to construct their own narratives.

\section{Results}

In this section, the results of the two teachers' self-studies of their own experiences as novice teachers are discussed. In addition, the way in which these teachers benefited from joining the online collaborative community is delineated. Direct quotations from the online journal and focus group interviews are identified in order to support their reflections where possible.

\subsection{Becoming an EFL Teacher in Japan}

The following stories involving Daisuke's and Taiki's experiences show that both teachers were initially influenced by their own English teachers in deciding to become instructors. This was in fact what Lortie [18] refers to as an 'apprenticeship of observation', a process that is often criticised because students unconsciously observe how their instructors teach [19]. However, their cases are different in that even early on in their careers, they became aware of the importance of both second language research and pedagogy to draw upon in making professional judgments.

\subsubsection{Daisuke’s Background}

I started to dream of becoming a teacher when I was a sixth-grader, partly because of one excellent teacher at that time, and also because of taking a pleasure in teaching something to my classmates, such as how to 
solve arithmetic problems. After majoring in English in college, I still found my English skills not high enough to teach in high school. Thus, I decided to go to graduate school to improve English skills, and further study second language acquisition (SLA) theories.

Having actual classroom experience while studying SLA theories in graduate school was one of the most influential factors that contributed to making me become a teacher who could bridge the gap between theory and practice. While working on a master's degree, inspired by other promising graduate students, I started working as an English teacher. I taught at a public middle school as a substitute teacher for three months and a private secondary school for a year. This experience enabled me to notice that an understanding of SLA theories itself is not enough to be a good teacher, and that theory needs to be adapted into an actual context. Now I work as a full-time English teacher at a music school consisting of high school and college, where I teach English to high schoolers and undergrads.

\subsubsection{Taiki's Background}

I have been teaching English at a high school since graduating from university. My motivation to teach English dates back to my high-school days. When I was in the second year, I met an English teacher with excellent teaching skills. I always enjoyed his classes and wanted to be like him. One day, he recommended me to participate in an English speech contest, and so I did. It was such a challenging experience that I had to write a long speech, revise it many times with his help, and recite it until I could remember all of it. Although I did not win the contest, this turned out to be a significant event in my English learning experience. After the contest, I realised that I could read English more easily than before. This experience encouraged me to further learn how people acquire a language. Since then, I have also developed an interest in the methodologies of English language teaching.

\subsection{Recognising Shifts in Perspective: What is a “Good” Lesson?}

In this section, both teachers reflected on how their perspectives toward a good lesson shifted over the year while being members of the community. Daisuke observed a significant change in his teaching practice of teaching speaking, while Taiki noticed in his reading-based classroom that using students' L1 as a medium of instruction can promote students' text understanding if used properly.

\subsubsection{Daisuke’s story}

I place heavy emphasis on fostering my students' intellectual curiosity so that they will become autonomous learners. This is the basis of my teaching belief, and it has not changed since a year ago. A significant change of my teaching practice, though, has occurred in the way of teaching speaking: from giving numerous chances to speak English extemporaneously to combining free conversation and memorisation.

Soon after I took a post at my current school, I felt the need to improve my students' speaking skills, because music-major students will have to communicate with and learn from musicians from other countries, especially European ones. Thus, I began incorporating speaking activities into my teaching and adopted an activity called "two-minute speaking" first. In this activity, students had to keep talking in English freely for two minutes about a certain topic I provided (e.g., a favourite movie, classical musicians they admire). I believed that a good English class should provide students with many opportunities to practice conversation skills in English. However, a little later on, I found this task to be fruitless and decided to experiment with other speaking activities: oral summary tasks (OS) and subsequent reproduction training (RT).

I initially thought that free conversation would lead to the development of speaking skills, and I encouraged my students to practice speaking during the two-minute speaking task. However, the problem of the task was that the content of their conversation was likely to be shallow and humdrum, which made me wonder why it did not develop more deeply. Gradually, I noticed that because of their limited vocabulary, they could not say what they wanted to say, so they ended up using simple phrases that they already knew, such as, "I like sushi because it's tasty. How about you?"

I eventually developed the belief that before giving students opportunities to speak, I need to provide input that includes vocabulary and grammar elements that they can use while speaking. Speaking is not something learners can do on a blank slate, but, as Krashen [20] rightly argues, learners need to gain enough input first before they can use what they have already taken in and produce the language. Consequently, I introduced OS as the antithesis of free conversation. In this activity, the students first have to read and understand passages. Then they make an oral summary of the passages in pairs by using some key phrases provided as a word list while constructing sentences in English with their prior grammatical and lexical knowledge. Using key phrases appropriately requires grammatical and collocational skills as well. They found it very demanding but meaningful, and I noted this in the journal as follows:

When I had them try the oral summary task, first they said, 'No way' but tried hard and seemed to feel accomplished.

[Daisuke, journal entry, 04/12/2018]

This excerpt illustrates that OS played a certain role in enhancing the students' speaking skills. It asked them to reuse the key phrases and co-construct sentences with the 
grammatical rules that they already possess.

However, during the second focus group interview in September 2018, Taiki said to me that a speaking activity could be done more flexibly. This dialogue enabled me to think about a new speaking activity that provides students with a chance to speak more spontaneously, while it helps them reuse some key phrases that they had learned from the passage. The following dialogue shows the actual conversation that we had regarding the speaking activity:

Taiki: If they can explain this story using their own expressions, you don't have to give them this word list.

Daisuke: Right.

Taiki: So, like, giving them this picture of Amy Cuddy, or just a few key phrases of the story.

Daisuke: Right, the main message. It's like the graphic organizer you said before.

Taiki: Yeah, yeah. Because this list has too many phrases, which, kind of, means they have to remember everything.

Daisuke: Remember ...

Taiki: Because they have to use all of the phrases to explain this story ...

Asaoka: You can try various styles of this kind.

Taiki: Yeah! It will work.

Daisuke: That's true. It can use some different aspects of storytelling. I don't have to provide the lists that my students have to consult to tell the story. [Second focus group interview, translated by Daisuke,

09/08/2018]

Also, for some students with high English proficiency, the given phrases were so restrictive that they could not fully utilise their speaking skills during the task. In other words, they could not summarize the story with their own expressions because the phrases they had to use were pre-selected. This was another reason why I thought I should improve the speaking activities in my teaching. At this point, I decided to change the Oral Summary to Reproduction Training (RT), which is another sort of story retelling activity.

RT served as a good solution in this situation. In RT, students first read a passage and then must explain and summarise the passage not with the given phrases, but with the aid of a "picture show" where the story of the passage is depicted in a four-cell manga ${ }^{1}$. The students explain the story either using their own expressions or borrowing the phrases in the reading passage they have read before-in the latter case, they have to recall them from the passage, though. I was satisfied with OS to some degree, but thanks to RT, I could make use of the

1 EIKEN, a widely used English proficiency test in Japan, uses a four-cell manga and asks test takers to describe the story, which is used to assess their speaking skills. advantages of both activities: free conversation and memorisation, since students explain the topic with their own words, and borrow the phrases they have learned in class simultaneously.

However, many students still struggle to perform RT. One time, they complained about the difficulty of this activity. Because of the use of limited productive vocabulary, some students still tried to memorise the whole sentences in the passage instead of explaining the story in their own words. To make RT more meaningful and accessible, I came to realise that choosing "a good passage" was important through writing the online journal, and reflecting on my teaching. As described below, a good passage should be easy for the students to read, and should include some key phrases that are necessary for daily conversation or academic learning. Also having students read it several times before RT is important so that they can understand the story well, and learn some key phrases for later use:

The fall semester has begun. The first lesson was about Steve Jobs, but the passage was difficult for them. I noticed that from my students' reactions during the class, they were struggling to understand the passage, which means that Reproduction Training was overwhelming for them, and they couldn't retell the story at all. I am wondering whether I should rewrite the passage so that they can focus more on speaking ${ }^{2}$. [Daisuke, journal entry, 09/27/2018]

Through my own teaching practice during this online project, I learned that no learner can engage in free interactive conversation from the start. Students need to first obtain abundant input, which is reusable in their speech. Meanwhile, mere memorisation of words and sentences may help students derive pleasure in speaking. Efforts to speak English by trial and error are necessary, which makes learning English more engaging. Thus, I came to realise that an appropriate balance between free conversation and memorisation is required for a good speaking lesson.

\subsubsection{Taiki's Story}

A year ago when I joined this project, I was trying to teach my class with a more student-centred and content-based approach. At the senior high school where I teach, many students try to enter high-level universities. Hence, English classes tend to be reading-oriented, focusing on reading comprehension through the translation method from English to Japanese, which usually requires students to answer comprehension questions in advance as homework. In such classes, students are more likely to be passive, and even when they are motivated to participate in class, it is difficult for them to concentrate on the teacher's one-way lecture for an

2 I eventually rewrote some passages a week later. 
entire class period. This is why I tried to provide many content-based tasks in class and have students work together. I believed that students would learn many more things by interacting with one another, absorbing new ideas on the contents they learn, and developing their grammatical and lexical knowledge at the same time.

A challenge for me at that time was to maintain a good balance among the various tasks in class. At the previous school I taught, the students enjoyed English classes more, and did not just cram knowledge, because not all of them would take university entrance exams. As an English language teacher, I could do various activities in class to draw their attention and stimulate their curiosity. However, at the current school, most students aim to get into prestigious universities. Thus, many teachers there give one-way lengthy lectures, and focus on reading texts and teaching grammatical forms during class. In such a class, students just check the answers for the comprehension questions and read texts aloud, which I thought was boring for them. For some, especially high-proficiency learners, there was not much that they could actually learn during class. On the other hand, for those who could not prepare well enough to participate in class, it was difficult to understand fully what they were learning.

I found it quite challenging in such a school context to make classes more communicative while focusing on reading. As one solution to improve my teaching practice, I asked my students not to prepare for the class. This way, they needed to concentrate more on learning in class, such as understanding the class content and using English. Furthermore, by doing various content-based activities during class, the students could participate more actively, which I believed was an ideal style for a foreign language classroom. The following dialogue illustrates why I decided to ask my students not to prepare for the class:

Taiki: For some high-level students, they can understand what they are going to learn when preparing for class. If a teacher talks during class and spends a long time lecturing, that must be quite boring for them. On the other hand, for some students who are very busy with club activities, it must be a big burden to check new vocabulary and answer many comprehension questions in advance. Considering these situations, I came to think that a classroom should be a place for everyone to be able to equally participate in, which makes students learn exclusively in class.

Asaoka: I see.

Daisuke: Sounds good. You know, it's a waste of time just to translate everything in a text when it is far more difficult for students. Checking what they prepared for is not efficient either. Rather, sharing what they already know is better for them to learn new things. (...) I understand you are not saying, "There's no need to study at home," but you are thinking more in terms of what they need to do in class, aren't you?

Taiki: Right.

[Second focus group interview, translated by Taiki, 09/08/ 2018]

Having received positive feedback about my idea from Asaoka-sensei ${ }^{3}$ and Daisuke in the second focus group interview, I became convinced that this approach would help my class become more communicative and student-centred. Therefore, when the autumn term began, I announced to my students that I was going to employ a new teaching style, and the students were basically glad to hear that it was no longer necessary to prepare for class. In the class, starting with an oral introduction, I encouraged the students to become interested in the textbook stories. Instead of explaining grammatical rules and translating the texts into Japanese, I planned activities that made them use English and understand the overall meaning of the texts, such as skimming, scanning, and keyword hunting.

The students seemed to enjoy each activity, but I was not sure whether it was successful or not. Some students asked me, "Is it okay to prepare for the next class?" or "Could you give us a Japanese translation?" These comments seemed to suggest a kind of anxiety about my new teaching style and activity-based class, but I continued to teach in that way for a while.

Since English was used as a means of instruction, the students participated in each activity using English. Although the amount of students' English usage increased, they (and also I) were not sure whether they really understood what the texts meant and what the story was about. As for input-related activities, such as skimming and scanning, it took more time to do them all than an English-Japanese translation activity because they were not used to a class conducted in English. The most crucial point of this approach, however, was that I did not have the opportunity to examine if they had a thorough understanding of the content during class. From this point-of-view, I realised that it is not always successful to conduct a class only in English.

I reported this experience on the online journal, and Daisuke immediately wrote some comments, which made me reflect back on how I felt in class:

Reading your journal entry, I thought that, as Hsueh-Chao \& Nation [21] suggest, it is difficult for students to understand what reading passages say unless they already know about 95 to $98 \%$ of the vocabulary in them. This means if they know less than $95 \%$, it will take a lot of efforts to look up the meanings of every unknown word and read them. ( ... ) There are many types of relatively easy reading materials for intermediate-level learners. I guess they

\footnotetext{
3 "Sensei” is a Japanese title for a teacher.
} 
will learn a lot more from reading those materials. Looking up new vocabulary words in difficult texts is not necessarily equal to good reading.

[Daisuke, journal entry, translated by Taiki, 10/04/2018]

Also Asaoka-sensei made a comment, saying that class preparation could function as scaffolding for the students with respect to actively participating in class. This comment made me realise that the students' first language, Japanese, should be utilised more positively so that they could participate in class without feeling any pressure or confusion. As many researchers argue with respect to classroom codeswitching, such as Turnbull [22], instructions in the students' mother tongue could be helpful, for example, to check their understanding. It could save time and could be appropriate for the EFL classroom, especially in a school environment in Japan with a class size of 40 students.

It was not until I changed my teaching style that I realised the importance of monitoring students' reactions to each language activity. Before that, I tried to maximise the use of English during class, which I believed then was the most imperative in having an ideal language classroom. Furthermore, I thought that it was absolutely wrong to teach English by just focusing on reading intensively with the teacher's instruction in Japanese, which hinders the development of students' productive skills. However, through changing my teaching style, I came to realise that using Japanese in the classroom can scaffold students' understanding and learning. Additionally, using Japanese in class enables learners to think carefully about the differences between the two languages, English and Japanese, and to acquire the skill of translating expressions that are unique to the English language (e.g., inanimate subjects) into Japanese. I used to believe that using Japanese should be limited during class, but it should be encouraged to promote effective teaching. Besides, I also realised that preparing for class in advance does not necessarily create a burden, but can work as scaffolding for students. As I realised this, I then tell my students about the meaning of lesson preparation and how to do it effectively. By guiding them in such a manner, both the students and I can recognise what we need to do before and during class. This was an important breakthrough in my professional learning as an English language teacher.

At the first school where I taught, I implemented language activities that I found to be effective. My students then seemed to enjoy them, and I did not have to think carefully about how these activities were coherently connected as a whole lesson. Hence, prior to participating in this project, I simply thought that a lesson should be taught in a content-based and student-centred way in order to maximise the use of English. Now I am more aware of the importance of understanding the meaning of each task, both with respect to the homework and in-class activities.
There is a need to check how each activity works in a lesson, and I must organise my class by monitoring the students' reactions to each activity. In addition, my view on English language teaching has changed greatly. I used to believe that the more students used English, the better their English skills would become. This is why my initial focus was on maximizing the use of English during class. However, I came to learn an effective way of using Japanese as assistance: scaffolding for EFL learners.

\section{Contribution of Joining an Online Collaborative Community of Practice to Professional Learning}

Participation in an online collaborative community of practice has enabled us to reflect on and adjust our teaching practices and develop our professional expertise. We discovered that the main characteristics of the collaborative and reflective process of our professional learning can best be described by what Daisuke referred to as being "a diagonal mentor". In the first focus group interview, while Taiki was expressing his frustrations with the lack of collegiality in his workplace, he mentioned a science teacher who asked him to work together and develop an exploratory learning element in a science course with the use of ICT. In responding to this, Daisuke mentioned the role of a diagonal mentor, and Taiki agreed with its importance:

Daisuke: I read this in a book the other day, that one's immediate boss cannot necessarily be a good mentor. He exists somewhere else, more diagonally, and you interact with and learn a lot more from such a diagonal mentor.

Taiki: You're right. It reminds me of a physics teacher who asked me to team-teach his class in English. If he teaches in English by himself, what he can do is simply translate what he usually lectures into English, so he decided to get me involved in lesson planning...By adding the perspective of an English language teacher, he was able to teach by asking students to use basic vocabulary in lectures and interact with one another in English, so collaborative lesson preparation with him was a good learning experience for me.

[First focus group interview, 04/01/2018]

A diagonal mentor is a concept that is often used in psychology and business fields, in which the relationship between one and one's mentor with relevant experience and expertise, being neither vertical (e.g., an immediate boss or supervisor) nor horizontal (e.g., classmates and peers), is valuable in professional learning [23]. By taking on the role of a diagonal mentor in the collaborative community we formed, we found a way to make our professional voices heard. Daisuke, using the famous German tale of Hansel and Gretel, described how we 
recorded our professional journey, and how it contributed to noticing new insights in his final reflection:

In Hansel and Gretel, Hansel threw crumbs on the path as a route marker. Keeping a collaborative journal where we wrote down everyday hassles and gave comments on them with each other, and having focus group discussions might be similar to throwing crumbs on the ground. I threw crumbs; Taiki and Asaoka-sensei also threw crumbs, and sometimes we could find a new path to a candy house, although the candy house in the story was the house of a wicked witch. What I mean is that seemingly unrelated things are essential in finding a creative solution. Our casual exchange of opinions significantly changed our ways of teaching.

[Daisuke, final reflection, February 2019]

Daisuke's final journal entry also suggests a similar sentiment:

Our noticing is very interesting. It's like, each of us already knows certain concepts individually, but we don't connect each understanding together, but at one point, we can abruptly connect them. I knew about Reproduction Training beforehand, and actually, I sometimes used this activity and found it to be meaningful. But I have never thought about using RT as being connected with the reading passages I use in my class. When Taiki's comments made me rethink about the speaking activities I used in class, I, for the first time, connected my thoughts and his on these activities together, and I came up with a better approach to using it. I want to continue connecting two or more different concepts together from now on.

[Daisuke, journal entry, 01/31/2019]

Taiki also stated the main benefit of participating in the collaborative community was discovering new insights and ways of teaching as a result of talking to himself about his own teaching practice and receiving feedback from the other members:

Thanks to the positive feedback from Asaoka-sensei and Daisuke, I could keep trying something new. Although Daisuke teaches in a completely different school setting, he gave me a lot of hints to improve my teaching practice. I learned that he makes his own teaching materials by himself and always teaches in a way in which the students enjoy the learning contents. This is exactly the same issue that I have tried to focus on, so I could learn a lot from his teaching.

[Taiki, final reflection, February 2019]

This sentiment was particularly important to Taiki, who was experiencing dissatisfaction with the lack of collegiality in his workplace. The online collaborative community not only created the space and the means for our professional voices to be heard, but it also provided a diagonal mentor for us. As Bullogh and Pinnegar [10] rightly state, we could share our experiences of introspection and personal growth as teachers, and we improved our teaching situations not only for ourselves but also for others.

In conclusion, the self-study community of practice, in which we collaboratively reflected on our teaching practices and shared our thoughts and ideas, has played a vital role in promoting our professional learning. The role of collegiality in sharing teaching strategies that had an impact on the teaching of English in diverse EFL context (public school and private school-both directing their graduates to different career trajectories) and for teaching different language skills (oral communication and reading/translation). We strongly believe that communication, collaboration, and collegiality (albeit necessarily within our own workplaces) are essential for the professional development of EFL teachers.

\section{REFERENCES}

[1] P.F. Hernández-Ramos. Web logs and online discussions as tools to promote reflective practice, Journal of Interactive Online Learning, Vol.3, No.1, summer, 2004.

[2] J. Dewey. How We Think, New York: Heath and Co., New York, 1993.

[3] D. McIntyre. Theory, theorizing and reflection in initial teacher education, In J. Calderhead, P. Gates (Eds.), Conceptualizing Reflection in Teacher Development (pp.39-52), Falmer Press, London, 1993.

[4] D.A. Schon. The Reflective Practitioner: How Professionals Think in Action. Basic Books, New York, 1983.

[5] D.A. Schon. Educating the Reflective Practitioner: Toward a New Design for Teaching and Learning in the Professionals. Jossey-Bass, San Francisco, CA, 1987.

[6] S. Kemmis, R. McTaggart. (Eds.) The Action Research Reader (3rd ed.), Deakin University Press, Geelong, Victoria, 2000.

[7] T. Russell. Tracing the development of self-study in teacher education research and practice, In J.J. Loughran, M.L. Hamilton, V.K. LaBoskey, T. Russell (Eds.), International Handbook of Self-study of Teaching and Teacher Education Practices (pp.1191-1210), Kluwer, Dordrecht, 2004.

[8] J. Loughran. Researching teacher education practices: Responding to the challenges, demands, and expectations of self-study, Journal of Teacher Education, Vol.58, No.1, 12-20, 2007.

[9] J. Whitehead. The Growth of Educational Knowledge: Creating your Own Living Educational Theories. Hyde Publications, Bournemouth, UK, 1993.

[10] R.V. Bullough Jr, S. Pinnegar. Guidelines for quality in autobiographical forms of self-study research, Educational 
Researcher, Vol.30, No.3, 13-21, 2001.

[11] T. Russell. How 20 years of self-study changed my teaching, In C. Kosnik, C. Beck, A.R. Freese, \& A.P. Samaras (Eds.), Making a Difference in Teacher Education through Self-study: Studies of Personal, Professional and Program Renewal (pp.3-18), Springer, Dordrecht, the Netherlands, 2006.

[12] E. Wenger. Communities of Practice: Learning, Meaning, and Identity. Cambridge University Press, UK, 1999.

[13] J. Lave, E. Wenger. Situated Learning: Legitimate Peripheral Participation. Cambridge University Press, UK, 1991.

[14] K.E. Johnson, P.R. Golombek. The transformative power of narrative in second language teacher education, TESOL Quarterly, Vol.45. No.3, 486-509, 2011.

[15] J. Williams, J.K. Ritter. (2010). Constructing new professional identities through self-study: From teacher to teacher educator, Professional Development in Education, Vol.36, No.1-2, 77-92, 2010.

[16] M.K. Kabilan, W.F.W. Adlina, M.A. Embi. Online collaboration of English language teachers for meaningful professional development experiences, English Teaching: Practice and Critique, Vol.10, No.14, 94-115, 2011.

[17] J.V. Lock. A new image: Online communities to facilitate teacher professional development, Journal of Technology and Teacher Education, Vol.14, No.4, 663-678, 2006.

[18] D.C. Lortie. Schoolteacher. Chicago, IL: University of Chicago Press Chicago, IL, 1975.

[19] C. Asaoka. Early Professional Development in EFL Teaching: Perspectives and Experiences from Japan, Multilingual Matters, Bristol, UK, 2019.

[20] S.D. Krashen. The Input Hypothesis: Issues and Implications. Laredo Publishing, Torrance, CA, 1992.

[21] M.H. Hsueh-Chao, P. Nation. Unknown vocabulary density and reading comprehension, Reading in a Foreign Language, Vol.13, No.1, 403-430, 2000.

[22] M. Turnbull. There is a role for the L1 in second and foreign language teaching, but.... Canadian Modern Language Review, Vol.57, No.4, 531-540, 2001.

[23] Coach-Therapy, Online available from http://coach-therapy.co.uk/diagonal-mentoring/ 